\title{
73. Svetlana Aleksiyeviç’in “Son Tanıklar: Çocukluğa Aykırı Yüz Öykü” eserinde çocuk belleğinde savaşın izleri
}

\section{Reyhan ÇELİK'}

APA: Çelik, R. (2021). Svetlana Aleksiyeviç’in “Son Tanıklar: Çocukluğa Aykırı Yüz Öykü” eserinde çocuk belleğinde savașın izleri. RumeliDE Dil ve Edebiyat Araștırmaları Dergisi, (24), 1230-1238. DOI: $10.29000 /$ rumelide.997576.

$\ddot{\mathbf{O} z}$

Bu çalışmanın amacı, sadece yetişkinlerin zarar gördükleri ve kayıplara uğradıkları düşünülen savaş olgusunun, aslında çocukların belleğinde daha çok yer ettiğini ortaya koymaktır. Savaş, insanlık tarihinin en önemli gerçeklerinden biridir. Farklı dönem ya da farklı kültürlerde de olsa savaşın sonunda ölüm, acı ve yok edişler vardır. Yirminci yüzyılda yaşanan iki büyük dünya savaşı, toplumların bütün fertlerini en acı şekilde etkilemiştir. Bu yüzyıl savaşlarında artık sadece erkekler aktif olarak rol almazlar; kadınlar ve çocuklar da ülkeleri için mücadele verirler. İkinci Dünya Savaşı, Birinci Dünya Savaşı'ndan çok daha ağır bedellerle sonuçlanır. Savaşın ardından her ülke, milyonlarca vatandaşını kaybetmiş, ekonomik ve psikolojik olarak yeniden ayağa kalkmaya çalışmıştır. Sovyet Rusya da Alman saldırılarıyla bu savaşa katılmak zorunda kalır. Sonunda da toplumun her kesiminden erkeği ve kadını ile bu savaştan galip çıkar. Ancak bu süreçte, ailelerin geride bıraktıkları çocukları da küçük ve temiz dünyalarından çıkıp yaşamın acı gerçekleri ile yüz yüze kalırlar. Belarus gazeteci-yazar Svetlana Aleksiyeviç 1985 yılında kaleme aldığı "Son Tanıklar: Çocukluğa Aykırı Yüz Öykü” kitabını o zorlu savaş yıllarını çocuk olarak yaşayan kişilerin, anlatımlarından oluşturur. Bu çalışmada söz konusu kitapta yer alan anı anlatılarından yola çıkarak savaş olgusunun ve özellikle İkinci Dünya Savaşının çocuk hafızasında kalan görünümleri nitel yöntemle irdelenmiştir. Dolayısıyla da savaşa maruz kalan çocukların yaşadıkları acıların farklı sarsıntılar şeklinde yaşamları boyunca belleklerinde yer ettiği sonucuna varılmıştır.

Anahtar kelimeler: İkinci Dünya Savaşı, bellek, çocuklar, ölüm, açlık

\section{Traces of war in the children's memory in Svetlana Aleksiyevich's "Latest Witnesses: Unchildlike Stories"}

\begin{abstract}
The aim of this study is to reveal that the phenomenon of war, which is thought to harm only the adults, is more common in children's memory. War is one of the most important facts in human history. There is death, pain, and destruction at the end of the war even it's in different periods or cultures. The two great world wars in the twentieth century affected all members of societies in the most painful way. In the wars of this century, not only men take an active part but also women and children fight for their country. The Second World War results in much heavier costs than the First World War. After the war, every country lost millions of its citizens and tried to rise up economically and psychologically. Soviet Russia is forced to participate in this war as a result of German attacks and wins it due to the efforts of its citizen from various backgrounds. However, in this period, the children left behind by the families also have to leave their safe zones and face the harsh realities of
\end{abstract}

Doç. Dr., Akdeniz Üniversitesi, Edebiyat Fakültesi, Rus Dili ve Edebiyatı Bölümü (Antalya, Türkiye), reyhan3104@gmail.com, ORCID ID: 0ooo-0002-9743-3720 [Araştırma makalesi, Makale kayıt tarihi: 13.08.2021-kabul tarihi: 20.09.2021; DOI: 10.29000/rumelide.997576]

RumeliDE Journal of Language and Literature Studies

Osmanağa Mahallesi, Mürver Çiçeği Sokak, No:14/8

Kadıköy - ISTANBUL / TURKEY 34714

e-mail: editor@rumelide.com

phone: +90 5057958124, +90 2167730616 
life. Belarusian journalist-author Svetlana Alexievich composes her book "Last Witnesses: Unchildlike Stories" which she wrote in 1985, from the narratives of people who lived through those difficult war years as children. In this study, which is based on the memoirs in the book, the appearances of the war phenomenon and especially the Second World War images in children's memory were examined using qualitative method. As a result, it was concluded that the pain experienced by children exposed to war remains in their memories in the form of different trauma throughout their lives.

Keywords: World War II, memory, children, death, famine

\section{Giriş}

"Savaş" kelimesi ister bir insanın kendisiyle savaşı olsun ister iki ülke arasında olsun isterse iki farklı dine mensup insanlar arasında olsun... Her durumda, savaşın sonunda zafer elde edilmiş olsa da kendisiyle birlikte bir mücadeleyi, fedakârlığı, kaybı ya da ölümü getirir. Savaş, nitelikleri ve boyutları farklı olsa da insanlık tarihinin ilk dönemlerinden günümüze kadar varlığını sürdüren ve bundan sonra da her daim devam edecek olandır. Savaşın yüzyıllar boyunca niteliğinde ve boyutlarında değişimler görülür. Örneğin Birinci Dünya Savaşı bu farklılığın en belirgin olduğu ilk savaş olarak düşünülür. Murat Belge, Birinci Dünya Savaşı ile başlayan savaş anlayışındaki değişimi ve yarattığı sonuçları değerlendirdiği yazısında, Birinci Dünya Savaşı'nın, yarattığı acımasızlıkla savaş romantizmini ve komutanların bireysel çabalarını geride bıraktığını belirtir:

"Birinci Dünya Savaşına kadar her ne kadar toplumsal tarihi boyutlar kazanmış olsa da savaş hala büyük ölçüde romantik bir olaydı. Bir kere büyük ölçüde yalnızca savaşanlarla sınırlıydi. İkincisi komutanlarn bireysel yetenekleri belirleyici sayılıyordu; başka bir deyişle, insan henüz savaşa egemen görüyordu kendini. Dünya savaşı bu romantizmi bir daha doğmamacasına yıktı. Dört yıl boyunca ölenlerin sayısı sivillerin ilk kez ciddi bir tehlikeye girmesi, modern savaşın centilmenliğe, şövalyelik oyunlarma yer brrakmayan acımasızlı̆̆ı, teknolojinin belirleyici rolü bu olayı yaşayan kuşaklarm iyimserliğini yerle bir etti.” (Belge, 2016: 442)

Dolayısıyla yirminci yüzyılın beraberinde getirdiği teknolojik gelişme, yaşam tarzı ve anlayışındaki değişimi de beraberinde getirmiştir. Artık savaşlar askeri boyuttan çıkıp çok daha acımasız bir hale gelmiştir. Bu nedenle de insanlığın tanıklık ettiği ve dünya tarihinin en kanlı iki savaşı olarak adlandırılan Birinci Dünya Savaşı ve ardından yirmi üç yıl sonra başlayan İkinci Dünya Savaşı toplumsal, ekonomik, teknolojik, psikolojik ve felsefi açılardan pek çok değişimi de beraberinde getirecek kadar güçlü etkilerle sonuçlanmıştır.

1941-1945 yılları arasında yaşanan açlık ve hastalıklardan dolayı ölümler de dahil edildiğinde, yaklaşık 60-80 milyon insanın öldüğü İkinci Dünya Savaşı insanlık tarihinin bugüne kadarki son büyük savaşıdır. Bu nedenle İkinci Dünya Savaşı ile ilgili farklı tarihçi ve araştırmacıların ortak yorumu, yirminci yüzyılın felaketler yüzyılı ya da savaş yüzyllı olduğudur. Örneğin tarihçi Eric Hobsbawm "Birinci Dünya Savaşı'nın patlamasından ikincisinin ertesine kadar geçen on yıllar, bu toplumun felaket çağı oldu. Toplum kurk yıl kadar bir beladan diğerine sendeleyerek ilerledi” (Hobsbawm, 2010: 21) derken diğer bir tarihçi yazar Norman Stone da "Birinci dünya savaşının başlamasıyla ikinci dünya savaşının sonu arasındaki otuz yıl, 1920’lerin ikinci yarısındaki kısa arahk hariç, felaketlerle dolu” (Stone, 2019: 8) olarak tanımlarlar.

İnsanlık tarihinin en büyük savaşları elbette ki toplumsal yaşamın bir aynası olan edebiyatta da yankı bulmuştur. Yirminci yüzyılın en büyük insanlık dramı olan İkinci Dünya Savaşı ile ilgili kaleme alınmış,

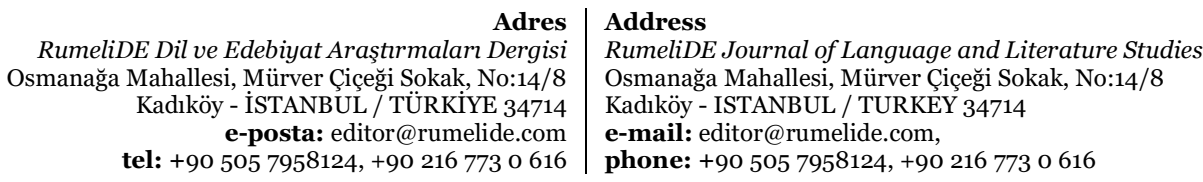


Traces of war in the children's memory in Svetlana Aleksiyevıch's "Latest Witnesses: Unchildlike Stories" / R. Çelik (pp. 12301238)

çoğunlukla da gerçek yaşanmışlıkları anlatan pek çok öykü, roman ve şiir bulunur. Bunlardan bazıları savaş yıllarında bazıları da büyük savaştan yıllar sonra kaleme alınmışlardır. Örneğin Cengiz Aytmatov'un "Cemile", “Toprak Ana” vb. romanları; Nobel edebiyat ödülü sahibi Alman yazar Günter Grass'ın "Danzig Üçlemesi” bir yandan yazarın dünya edebiyatlarında tanınmasını sağlarken diğer yandan da İkinci Dünya Savaşı'nın anlatıldığı en güzel romanlar arasında yer alır. Ayrıca Polonyalı yazar Jerzy Kosinski'nin "Boyalı Kuş" ( The Painted Bird, 1965 ) romanı ve Cengiz Dağcı'nın "Korkunç Yıllar" (1989) vb. gibi daha pek çok benzer roman farklı açılardan İkinci Dünya Savaşı’nı anlatır.

Savaşın farklı boyutları ve farklı kişilerdeki etkileri üzerine kaleme alınmış söz konusu örnekler, bunlardan sadece bir kaçıdır. Cephedeki savaş, cephe gerisindeki savaş, açlıkla savaş, ölümle savaş, özlemlerle savaş, insanın kendisi ile savaşı... Bunların her biri farklı bakış açıları ile eserlerde anlatılmaya çalışılmıştır. Ancak az önce de belirtildiği gibi yirminci yüzyılda savaşların niteliği ve boyutları da değişmiştir. Artık savaş, yalnızca yetişkinleri değil dünya geleceğini ifade eden çocukları da içine alır. Dolayısıyla çocuk bakışı ile savaşın görünümü ve anlamı otobiyografik ya da kurgu olsun pek çok eserde dile getirilirken bunlardan bazıları da beyaz perdeye uyarlanmıştır. Örneğin Nazi işgalindeki Hollanda'da Bergen -Beslen toplama kampında yaşamak zorunda bırakılan ve tifüs hastalığından ölen Anne Frank bunlardan yalnızca biridir. Henüz on beş yaşında olan Anne Frank’ın günlük notlarından yola çıkarak ortaya çıkarılan “Anne Franke’ın Günlüğü” (Het Achterhuis, 1947 ) adlı bu eser çocuk iyimserliğini, umudunu ve savaş karşıtlığını çocuk bakış açısı ile anlatması açısından önemli otobiyografilerden biridir. 1959 yllında beyaz perdeye de uyarlanan “Anne Franke’ın Günlüğü” gibi John Boyne'nin "Çizgili Pijamalı Çocuk” (The Boy in the Striped Pyjamas, 2006 ) ve Markus Zusak'ın “Kitap Hırsızı" (The Book Thief, 2006) adlı eserleri de savaşın çocuklar üzerindeki büyük etkileri üzerine kaleme alınmıştır. Dolayısıyla kurgu ya da gerçek olsun, çocuk bakış açısıyla kaleme alınan tüm kitaplar İkinci Dünya Savaşı'nın farklı gözlerden ve farklı anlayışlardan birer yansımasıdır.

Sovyet Rusya da Nazi Almanya'sının saldırılarıyla İkinci Dünya Savaşı'na giren ve dört yılın sonunda savaşı lehine sonuçlandıran ülkelerden biridir. Asker ve sivil, yaklaşık yirmi yedi milyon insanın ölümü ile sonuçlanan bu acımasız savaş, Sovyet Rusya'nın edebiyat tarihinde, bir savaş edebiyatı yaratmıştır. Savaşın ilk günlerinden başlayarak marşlar, şarkılar, makaleler, şiirler ve öyküler kaleme alınmış, böylece asker ve sivillere galibiyet inancı verilmeye çalışılmıştır. Örneğin Aleksey Tolstoy'un "Zaptedilemez Kale" (Nesokruşimaya krepost, 1942), "İvan Sudarev'in Öyküleri” (Rasskazı İvana Sudareva, 1942) ; Konstantin Simonov'un "Bekle Beni” (Jdi menya, 1942) şiiri; İlya Erenburg’un "Öldür Almanı"(Ubei Nemtsa, 1942) şiiri ve "Nefret Hakkında" (O nenavisti, 1942) adlı makalesi; Aleksandr Fadeev'in "Genç Muhafiz" (Molodaya gvardiya, 1945), "Kuşatma Günlerinde Leningrad” (Leningrad v dni blokadı, 1944) eserleri bunlardan yalnızca birkaçıdır.

Dokuz Mayıs 1945’teki büyük galibiyetin ardından da geride kalan savaş yıllarının anlatıldığı pek çok eser kaleme alınır. K. Simonov’un "Silah Arkadaşları" (Tovarişi po orujiyu, 1952), "Yaşayanlar ve Ölüler" (Jive i mertvie,1959) romanları ile "Ölüyor Dostlarım Ölüyor" (Umirayut druzya, umirayut, 1970) şiiri; Mihail Şolohov’un "İnsanın Kaderi” (Sudba çeloveka, 1957) adlı büyük romanı bunlardan bazılarıdır. Bu eserlerde artık sadece o yıllardaki büyük başarılar, birlik duygusu, erkeği ve kadını ile tüm Sovyet

“Teneke Trampet”, (Die Blechtrommel,1959), “Kedi ile Fare”,(Katz und Maus, 1961 ), “Köpek Yllları” (Hundejahre, 1963) adlı üç yapıtı, Danzig Üçlemesi’ni oluştururlar. Üç romanın ortak paydası İkinci Dünya Savaşıı'nın anlatılması ve konularının Danzig'de geçmiş olmasıdır. Romanlarda yirminci yüzyll realist bir șekilde elestirilmis ayrıca savaş öncesi ve savaş sonrası Almanya kıyaslanarak ikinci dünya savaşının yıkımları gözler önüne serilmiştir. "Teneke Trampet” romanı sinemaya da uyarlanır. 
insanının gücü ve inancı değil aynı zamanda savaşla birlikte insandan kopup giden duygular da dile getirilmiştir.

Babası Belarus annesi Ukraynalı olan ve Ukrayna'da doğup büyüyen gazeteci ve yazar S. Aleksiyeviç’in (1948- ) kaleme aldığı kitaplar da "savaş" üzerinedir. Yirminci yüzyıl Sovyet dönemi Rus edebiyatında belirgin olmaya başlayan sanatsal-belgesel edebiyat S. Aleksiyeviç’in tüm kitaplarında ortak temel özellik olarak dikkat çeker. Dolayısıyla bir gazeteci olarak S. Aleksiyeviç'in ilgi odağı, ülkenin yakın tarihinde yaşanan olaylar ve bunların toplumsal ve psikolojik sonuçlarıdır. Bunu şu sözleri ile dile getirir:

SSCB dönemine ve sonrasına dönüp baktı̆̆ımızda, tarihimizin koca bir mezar ve büyük bir kan banyosundan ibaret olduğunu görürüz. Kurbanlarla cellatlar arasındaki tükenmek bilmez dialogları duyarız. Sürekli olarak karşımıza aynı lanetli sorunsallar çıkar: Ne yapmal, suçlu kim? Devrim, toplama kamplar, ikinci dünya savașı, Sovyet-Afgan savașı strasında halktan gizlenen gerçekler, büyük bir imparatorluğun çöküşü, devasa ölçekte bir sosyalist ütopyanın paramparça dağılması, yeni ortaya çıkan evrensel problemler, Çernobil faciası vs. Bunlar, dünya üstündeki tüm insanların cevaplaması gereken sorulardır ki, tümü bizim kendi gerçek tarihimizdir. İşte tüm bu cehennemden çıkma soru ve sorunlar, benim kitaplarmmn izleğini oluştururlar. (Emir, 2016: 149)

“İkinci El Zaman- Kızıl İnsanın Sonu” (Konets krasnogo çeloveka, 2013), "Savaşın Kadın Yüzü Yok” (U voynı ne jenskoye litso, 1985 ), "Çinko Çocuklar" (Tsinkovıye malçiki, 1991), "Son Tanıklar-Çocukluğa Aykırı Yüz Öykü” (Poslednie svideteli- sto nedetskih rasskazov,1985), Çernobil Duası: Geleceğin Kroniği” (Çernobılskaya molitva: hronika buduşego, 1997) vs. hepsi Sovyet dönemindeki Rus insanının gerek kendi insanıyla gerekse farklı milletlerle olan savaşını dile getirilir. Adı geçen kitaplar, Rusya'nın yirminci yüzyıldaki tarihsel olaylarından yola çıkılarak kaleme alınmıştır. Kitaplar, bu olayları bire bir yaşayan, toplumun her kesiminden farklı yaşlardaki insanlarla yapılan röportajlar, günlük sohbetler hatta gelip geçerken yazarın kulağına gelen yorumlardan oluşur. Yazarın ifadesi ile kaleme aldığı kitaplar, seslerin birer birleşimidir. Nitekim Nobel edebiyat ödülü konuşmasında edebiyata yaklaşımını tanımlarken kendisini "kulak-insan" olarak tanımlar:

"Flaubert, kendisi için "kalem -insan" demiş ben de kendim için "kulak-insan" diyebilirim. Sokakta yürüdüğüm zaman, kulağıma birtakım kelimeler, sözler, nidalar çalındığında, hep şunu düsünüyorum: zamanla ne kadar çok roman, iz bile brrakmadan kayboluyor. Karanlı̆̆a karışıyor." (Aleksiyeviç, 2015)

Dolayısıyla S. Aleksiyeviç’in kaleme aldığı kitaplarda, zamanın içinde yaşanan olayları ya da bu olayları yaşayan kişileri tekil olarak düşünmediği görülür. Her ne kadar birebir sohbetler sonucunda oluşturulmuş olsa da aslında her biri kendi sesi ile ortak bir şarkıyı seslendirmektedirler. Bu şarkıda acı, açlık, ölüm ve her türlü kötülük anlatılır.

\section{Bulgular}

Belirtildiği gibi S. Aleksiyeviç’in kitaplarında zorlu yirminci yüzyıl tarihine tanık olan her kesimden ve her yaştan insan vardır. Bunlar arasında çok küçük yaştaki çocuklar da yer alır. Savaş denildiğinde, yüzyıllardır süre gelen bir anlayışla, aklımıza ilk olarak genç ya da yaşlı olsun erkek ölümleri, kayıpları ya da sakatlanmaları akla gelir. Ancak çocuklar savaşın yok ettiği, geleceğin ifadesi en değerli varlıklardır. S. Aleksiyeviç’in İkinci Dünya Savaşı yıllarına geri dönerek 1985 yılında kaleme aldığı “Son Tanıklar-Çocukluğa Aykırı Yüz Öykü” ( Posledniye svideteli- Sto nedetskih rasskazov ) adlı kitabı da çocukların seslerinden oluşur. Bu sesler biz okuyuculara kaybolmuş bir çocukluğu, anne ve baba özlemini, açlık duygusunu ve en önemlisi de ölüm duygusunu anlatır.

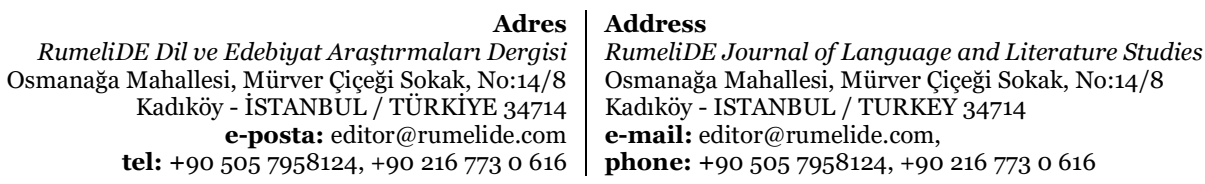


Traces of war in the children's memory in Svetlana Aleksiyevıch's "Latest Witnesses: Unchildlike Stories" / R. Çelik (pp. 12301238)

$\mathrm{Bu}$ çocuklar, acımasız savaş yıllarındaki zorlu yaşam mücadelesi sonucunda hayatta kalmış olsalar bile savaş, yaşamlarında her daim onlarla birlikte varlığını sürdürür. Savaşın ne demek olduğuna, ailenin ve toplumun yaşadığı yıkıntılara, kayıplara çok küçük yaşlarında şahit olmak zorunda bırakılırlar. Bu nedenle geçmişe dönüp o yılları düşünen anlatıcıların pek çoğu "Hayır, çocuk olmadım ben. Kendimi çocuk olarak hiç hatırlamıyorum” vb. cümleler kurarlar. O yıllarda yedi yaşında olan Nadya Gorbaçeva "Yillar geçti... bir sürü kitap okudum. Fakat çocukluğumda bildiklerimden daha fazlasını öğrenmedim savaş hakkında." (Aleksiyeviç, 2019: 124) derken bir duyguyu yaşamak ile hissetmeye çalışmanın bambaşka şeyler olduğunu anlatmaya çalışır. Aslında savaş yılları, kendi yaşamlarının tarihlerini başkalarının yazdığı yıllardır. O korkunç yıllarda henüz dört yaşında olan Vasya Harevski "Savaş benim tarih kitabım. Yalnızhğım... Çocukluğu olmayan biriyim ben, çocukluk yıllartm yerine savaş var hayatımda. (Aleksiyeviç, 2019: s. 35 ) derken tüm çocukluk yıllarının savaş gerçekleri ile kaplı olduğunu ifade eder. Dolayısıyla, bir çocuğun belleğindeki savaş gerçekleri; hissettiği ölüm korkusu, açlık duygusu, anne ve baba özlemi... hepsi geride kalan çocukluk ylllarının birer ifadesi olarak kalmıştır.

Ölüm, her canlı varlık için; her türlü hayvan, çiçek, çocuk, genç, yaşlı, kadın ve erkek için söz konusudur. "Savaş" da "ölüm” kelimesini beraberinde getirir. Başka bir değişle savaş, anlamını ölümde bulur. Sigmund Freud "Savaş ve Ölüm Üzerine Düşünceler" (Zeitgemäßes über Krieg und Tod,1915) adlı kitabında yakınlarımızın ölümleri ile karşılaşıncaya kadar kişilerin ölümü yadsıdığını, ayrıca artık, savaş zamanında karşılaşılan ölümlerin doğal devinimin dışında olduğunu da ifade eder:

"Savaşın ölüm karşısında takındığımız bu geleneksel tavrı silip atmak zorunda kaldiğı açıkça ortada. Burada ölüm inkâr edilebilecek değil artık; hepimiz ona inanmaya mecburuz. İnsanlar gerçekten de ölüyorlar ve artık teker teker de değil üstelik topluca, tek bir gün içinde on binlercesi olmak üzere.” (Freud, 2018: 36)

Dolayısıyla yetişkinler için savaş kelimesi, ölümle aynı anlama gelirken savaşın ilk gününe kadar hayaller ve güzelliklerle dolu çocuk dünyasında ölüm, henüz kendisini tanıtmamıştır. Yedi yaşındaki Lena Kravçenko da savaşla birlikte ölümü tanıdığını şöyle ifade eder: "Ölüm hakkında, elbette hiçbir şey bilmiyordum... kimsenin bana ölümü anlatacak firsatı olmamıştı, ansızın çıkmıştı karşıma...” (Aleksiyeviç, 2019: s.96) On iki yaşındaki Gena Yuşkeviç de savaşın başladığı ilk gün savaşın yalnızca erkekleri değil tüm canlıları hayattan aldı̆̆ını fark eder. "Önce... önce ölmüş bir at gördüm... sonra... ölmüş bir kadın... şaşırmıştım buna. Savaşta sadece erkeklerin öldüğünü sanıyordum. (Aleksiyeviç, 2019: S.11)

Çocuklar savaş yıllarında sadece ölüm gerçeğinin varlığını kavramakla kalmaz gözlerinin önünde kendi yaşıtları olan çocukların acımasızca katledilişlerine de şahit olurlar. Kendisine savaş sorulduğunda "istemiyorum... brakan hatırlamayı, "savaş" kelimesini telaffuz etmek dahi istemiyorum"(Aleksiyeviç, 2019: s. 88) diyen on bir yaşındaki Lyuba Aleksandroviç köylerindeki partizan çocuklarının nasıl acımasızca öldürüldüğünü şu sözlerle hatırlar:

"Almanlar evlerimize dalmıştı... partizanlara katılanların çocuklarını topladılar... ve köyün orta yerinde kafalarm kestiler... bize de seyretmemizi emretmişlerdi. Evlerden birinde kimseyi bulamadılar, kedilerini yakalayıp astılar...”(Aleksiyeviç, 2019: s.89)

Çocuklar bir yandan ölümün en acımasız haline tanık olurken, tanınmaz haldeki cesetleri renklerine göre ayırmayı da öğrenmişlerdir. Savaşın getirdiği yangın ve yıkımın içinde hayatta kalmayı başaranlardan biri de on üç yaşındaki Katya Korotayeva'dır. Minsk'de yaşayan Katya, ilk gün yoğun bombardıman ateşine maruz kalan şehrin sokaklarında gördüğü manzarayı şöyle dile getirir: "Yürüyorsun yerde kapkara bir ceset, yanan yaşh bir adam demek. İleride küçük, pembe bir şey

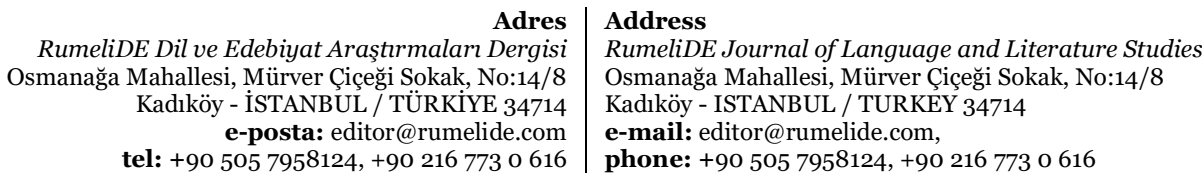


görüyorsun, demek ki yanan bir çocuk. Kömürleşmiş kalıntılar üzerinde pembe pembe yatıyorlard.." (Aleksiyeviç, 2019:s.17)

Daha önce de belirtildiği gibi, savaş boyunca partizan çocukları ve eşleri ortaya çıkarılarak acımasızca öldürülmüsslerdir. Yedi yaşındaki Volodya Korşuk'un annesinin Alman askerleri tarafından öldürülmesine verdiği tepki oldukça anlamlıdır. Çocukluğun verdiği saf duygularla dedesine sorduğu soru, ölümü kabulleniş ama ölüm şeklini kabullenmeyişin göstergesidir:

“...Annemi getirdikleri ana dair hatırladiğım şey, onu yüzünden vurdukların fark edişimdi: yanağında birkaç tane siyah kurşun deliği vardı. Dedeme sorup duruyordum sürekli: "Neden yüzünden vurmuşlar ki sanki? Oysa annem ne kadar güzeldi...” (Aleksiyeviç, 2019: s.113)

Köyleri ve mezarlıkları bombalanan beş yaşındaki Vanya da ölülerin bile yeniden öldürüldüğünü anlatır.

“Köyümüzü yaktılar. Köy mezarhğını bombaladılar... Ölüler toprağın üstünde yatıordu... Sanki bir kez daha öldürülmüş gibi uzanıyordu hepsi... Kısa süre önce ölen dedem de yatıyordu yerde. Hepsi yeniden gömüldü...”"(Aleksiyeviç, 2019: s.45)

Bir Alman askerini öldüren sekiz yaşındaki Vasya Saulçenko da ölümün, yaşamlarının ayrılmaz bir parçası olduğunu “...Bir sürü ölü vardı etrafta, ölülerin arasında yaşıyorduk. Hatta alışmıştık bile buna" (Aleksiyeviç, 2019: s. 272) diyerek ifade eder. Ardından da İkinci Dünya Savaşı'nı yaşayan neslin aslında bambaşka bir dünyanın insanları olarak yaşadıklarını düşünür:

“...Insanın insanı öldürdüğünü görmemiş insanlar, bambaşka bir dünyanın insanlarıdır” (Aleksiyeviç, 2019: s. 273)

Savaş yıllarında çocuklar yalnızca ölümün pek çok şekline şahit olmazlar çoğu zaman ölüm kendilerini de bulur. On dört yaşındaki David Goldberg savaşın ilk gününe denk gelen, öncü kamp açılışında yer alanlardan biridir. Onlarca arkadaşının bombardımanlardan ya da açlıktan dolayı gözlerinin önünde ölmelerini şöyle anlatır:

“Şunu söyleyeyim size, belki biliyorsunuzdur: Savaş zamanı çocuk olanlar, çoğu kez cephede savaşan babalarından önce öldü. Savaş zamanı asker olanlardan önce... Onlardan önce... O kadar çok arkadaşımı gömdüm ki ben...” (Aleksiyeviç, 2019: s. 93)

Savaşın yarattığı acımasızlıklar ve ölümler, çocukların saf ve güzel ruhlarında nefret duygusunu da filizlendirir. Nitekim on yaşındaki Saşa Kavruz diğer çocuklarla birlikte partizanlar tarafından ölümden kurtarllır. Saşa'ya "Yılbaşı ağactmın altında şekerleme mi? Kurabiye mi? Yoksa bir parça ekmek mi istersiniz?" diye sorarlar. O da "bir avuç mermi” diye yanıtlar." (Aleksiyeviç, 2019: s. 84)

Tarihteki pek çok savaşın gerçeği olan açlık, İkinci Dünya Savaşı'nın da en büyük gerçeği olmuştur. Anlatıcıların cümlelerinde ölümle birlikte açlık kelimesi de sık sı yinelenir. Hemen hepsi savaş yıllarındaki çocukluklarına döndüklerinde, hissettikleri açlık için "Sürekli yemek yemek istiyorduk", "Bir türlü doymak bilmiyorduk", "Hep açtım, sürekli bir şeyler yemek istiyordum" gibi cümleler kurarlar. (Aleksiyeviç, 2019: s.47; s.19; s.69) Babası ölen on yaşındaki Vera Taşkina acıktıkları zaman yemek yerine çorba kaselerinde su içtiklerini “Yemeklerde... su yiyorduk... öğle yemeği saati geldiğinde annem masaya bir tencere su koyuyordu. Biz de suyu çorba kaselerine koyuyorduk... akşam yemeğinde. Masada bir tencere sıcak su oluyordu... kışın da suyu renklendirecek herhangi bir şeyimiz yoktu. Çimen bile olmuyordu." (Aleksiyeviç, 2019: s.58) sözleriyle dile getirir. Hatta erkek kardeşinin açlık duygusunu bastırabilmek için tuğla sobanın kenarını kemirdiğini söyler: "Erkek kardeşim açlıktan

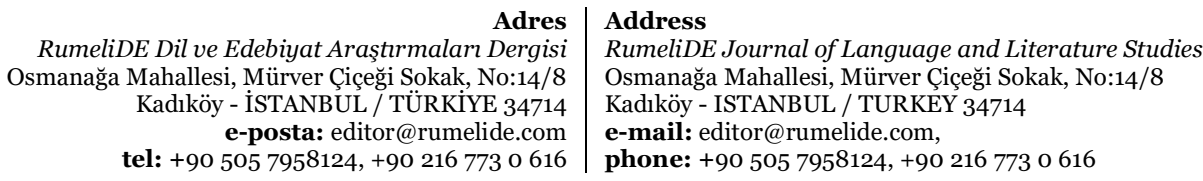


Traces of war in the children's memory in Svetlana Aleksiyevıch's "Latest Witnesses: Unchildlike Stories" / R. Çelik (pp. 12301238)

duvardaki taş firının kenarın yemişti. Biz firının kenarında çukur oluştuğunu fark edene dek her gün, her gün kemirmişti firmı." (Aleksiyeviç, 2019: s.58)

Yedi yaşındaki Nina Roçitskaya da annesi ve iki küçük kardeşi ile zapt edilen evlerinde Alman subaylarla birlikte yaşamak zorunda kalmıştır. Almanların pişirdiği yemek kokuları ile bastırılamaz hale gelen açlık duygusunu anlatırken dört yaşındaki kardeşinden bahseder:

“O kadar aç九 ki kardeşim, anneme, "hadi yavru ördeğimi pişirelim bile demişti. Oysa yavru ördek onun en sevdiği oyuncă̆ıyd, daha önce başka birine ödünç verdiği dahi olmamıştı. Onunla uyurdu geceleri." (Aleksiyeviç, 2019: s.64)

Yedi yaşındaki Lilya Melnikova da savaş yıllarında yetimhanede kalabilen şanslı çocuklardan biridir. Yetimhaneye ulaştıklarında kendilerine verilen bir parça ekmek karşısında hissettikleri mutluluğu "Yemeden duruyorduk, yediğimiz an bu mutluluğun sona ereceğinden korkuyorduk. Böylesi bir mutluluk gerçek olamazdı...” (Aleksiyeviç, 2019: s.78) sözleriyle dile getirir.

Beş yaşındaki Valya Matyuşkova da Alman toplama kampına götürülen yüzlerce çocuktan sadece biridir. Yaşının küȩük olmasından dolayı bazı olayları tam olarak hatırlamasa da yaşadıkları açlık gerçeğini çok ayrıntılı bir şekilde anlatır:

“... Henüz yürümeyi öğrenmemiş çocuklar vardı, emekleme çağındalardı. Karınları acıkınca yeri yalarlardi... yerdeki çerçöpü yerlerdi... çabucak öldü onlar. Çok kötü besleniyorduk, ekmeğe benzer bir şey veriyorlard bize, yiyince dilimiz şişiyordu, hatta öyle çok şişiyordu ki artık konuşamıyorduk. Yemekten başka bir şey düşünemez haldeydik. Kahvalt ederken düşünüyorsun; öğle yemeğinde ne var acaba? Ỏğle yemeği yerken, akşam yemeğinde ne verecekler acaba? Tellerin altından sürünerek geçip kente sıvışırdık. Tek bir hedefimiz vardı: çöplük. Ringa bahı̆ı derisi ya da patates kabuğuna denk gelmek akıl almaz bir mutluluktu. Çiğ çiğ yerdik kabukları.” (Aleksiyeviç, 2019: s. 99)

Her çocuk anne baba sevgisi ile büyür ve dünyayı tanır. Onlar sayesinde yaşama uyum sağlamayı ve kendi ayakları üzerinde durmayı öğrenir. Savaşın çocuklar üzerinde yarattığı belki de en büyük travmalardan biri de annelerine ve babalarına duydukları özlemdir. Onların koruması ve güven ortamlarına özlem duyarlar. Onların sarılmalarını özlerler. S. Aleksiyeviç’in kitabından duyulan seslerin en büyük özlemlerinden biri de anne ve baba sıcaklığıdır. Savaş başladığı gün öncü kampında bulunan ve ardından yetimhaneye götürülen sekiz yaşındaki Zina Kosyak kendisi gibi tüm çocukların yaşadığı anne-baba özlemini şu sözlerle hatırlar:

"Geceleyin kıyamet kopardı. Çı̆̆lık çığhğa annemizi babamızı çağırırdık. Öğretmenler bizimle konuşurken "anne" kelimesini kullanmamaya çalışırdı. Bize bu kelimenin geçmediği masalları anlatır, bu kelimenin geçmediğ i kitapları seçerlerdi. Birinin ağzından ansızın anne kelimesi çıkacak olsa o an kıyamet kopardl. Asla dindirilemeyen bir kıyamet.”(Aleksiyeviç, 2019: s.19)

Yaşananları anlattığı sırada elli bir yaşında olan Zina, içinde dindiremediği anne özlemini "Artık elli bir yaşıma geldim, kendi çocuklarım var. Ama hala annemi istiyorum” diyerek ifade eder.

Savaş başladığında dört yaşında olan ve tek başına bir istasyonda bulunarak yetimhanede büyüyen Marina Karyanova da "Hep açtım, sürekli bir şeyler yemek istiyordum. Ama yemekten daha çok istediğim şey birinin bana sarlmasl, şefkat göstermesiydi” (Aleksiyeviç, 2019: s.69) diyerek içindeki özlemi dile getirirken, hiç tanımadığı bir kadından dilendiği şefkati de unutmamıştır:

Yolda yürüyordum...Önümde çocuklarıla yürüyen bir anne vardl. Çocuklardan birini kucağında taşıyordu kadın, sonra onu birakıp diğerini alıyordu kucağına. Bir banka oturdular. Orada öylece

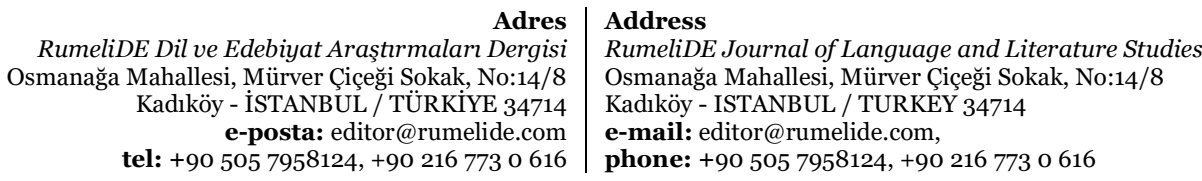


durdum, durdum... Sonra yanlarına yaklaştım: "Teyzeciğim, beni kucağınıza alır mısınız? Şaşırdı kadıncağız. Yineledim ricamı: “Teyzeciğim lütfen...”"(Aleksiyeviç, 2019: s. 69)

On iki yaşında bir asker çocuğu olan Valya Brinskaya da savaşın başından sonuna kadar annesi ve kardeşleriyle birlikte babalarını beklediklerini ve bu duygunun bir alışkanlık haline geldiğini şöyle anlatır:

"Babam gerçekten geldi mi? Bundan sonra babamı görebileceğime inanamıyordum, çünkü biz onu beklemeye alışmıştı. Bizim gözümüzde baba, beklenecek biriydi, babalar sadece beklenirdi.” (Aleksiyeviç, 2019: s.290)

Az önce de belirtildiği gibi savaşın çocukları, çocukluğun doğasını yaşayamazlar. Onlar bir yetişkin gibi davranmak ve hissetmek zorunda kalmışlardır. Bir kız çocuğunun oyuncak bebekle ya da erkek çocuğunun kendine has oyunlar ya da oyuncaklarla oynaması gerekir. Ancak İkinci Dünya Savaşı'na maruz kalan çocuklar bu duygulardan uzak büyürler. Hatta yetişkin olsalar da geride kalan, çalınan çocukluklarında kalırlar. Valya Brinskaya ve kız kardeşi de çok sevdikleri oyuncak bebekleri ile oynayamamanın özlemini içlerinde hissederler. Valya bunu "savaştan kız kardeşimle benim payıma düşen yegâne alş̧kanlık şu oldu: Sürekli oyuncak bebek alıyorduk. ...Belki de çocukluğumuzu...O çocuksu neşeyi yeterince yaşayamadiğımız içindir” (Aleksiyeviç, 2019: s.291) sözleriyle anlatır. Ardından da yllar sonra, kız kardeşi doğum yaptığında ona ne istediğini sorduğunu, onun da kendisinden oyuncak bebek istediğini anlatır:

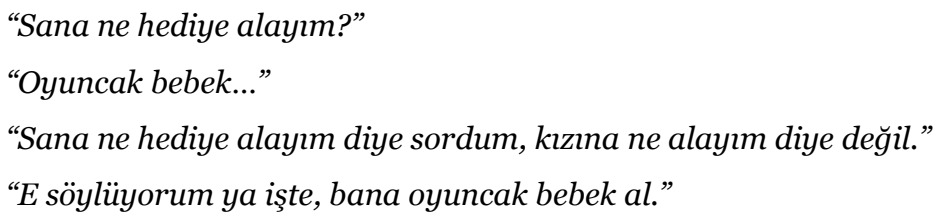

Farklı doğal afetler, yıkımlar vb. toplumu bir araya getiren, birlik beraberlik duygusunu canlandıran olaylardır. Savaș olgusunda da birlik beraberlik duygusu, galibiyete inanç duygusu olduğu zaman gelişmeler toplumun lehine ilerler. Savaş zamanında "yabancı" kelimesi sadece düşmanlar için kullanılır. Nitekim anlatılan bütün zorlu yaşam hikayelerinde birisinin ya da birilerinin yardımlarından bahsedilir. Her bir çocuk ya akrabalarından ya da hiç tanımadı ̆̆ı insanlardan yardım almıştır. O zorlu yıllarda annesiz babasız kalan Nina Şunto da kardeşi ve kendisine yardım eden, onları hayatta tutmaya çalışan insanları düşünerek, bütün kayıplarına ve kötülüklerine rağmen savaşın birleştirici bir unsur olduğunu söyler. Savaştan geriye kendisinde ne kaldığı sorulduğunda da "yabancı" diye bir kelimenin varlığını kabul etmediğini ancak zaman zaman da hayal kırıklığına uğradığını belirtir:

"Yabancı ne demek? Bunu almıyor kafam... Bizi tanımadığımız insanlar kurtardı. Onlar benim için neden yabancı olsunlar ki? Bütün insanlar yakınımız. İçimde bu duyguyla yaşıyorum ben, gerçi sık sık hayal kırıklı̆̆na uğruyorum. Savas sırasında süren yaşamla savas olmadığı zaman sürüp giden yaşam birbirinden farkh...”(Aleksiyeviç, 2019: s. 91)

\section{Sonuç}

Tüm dünyada milyonlarca kişinin ölümü ile sonuçlanan ve geride acıları, özlemleri bırakan İkinci Dünya Savaşı yalnızca yetişkinlerin değil çocukların yaşamlarında da çok kalıcı izler bırakır. Dolayısıyla savaş, katılan tüm ülkelerde olduğu gibi Rus toplumunda da sosyolojik, psikolojik ve felsefi sonuçları da beraberinde getirmiş, kısacası acılar, ölümler yalnızca toplumun belirli bir kesiminde değil topyekün yaşanmıştır.

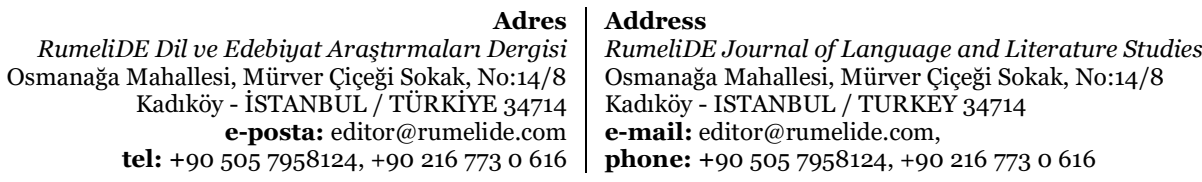



1238)

İkinci Dünya Savaşı’nda ölen milyonlarca insan arasında yaşamını kaybeden milyonlarca da çocuk vardır. Bununla birlikte sağ kalmayı başaranlar da ağır travmalarla birlikte yaşamaya devam etmiştir. Dolayısıyla savaş bittiğinde çocukların atlattıkları düşünülen sorunlar, aslında yıllar boyunca belleklerinde kötü anılar olarak kalmıştır. Savaşın üzerinden yıllar geçmesine rağmen her birinin belleğinde çocukluğunu yaşayamama duygusu, anne-baba özlemi, bir lokma ekmeğin kıymeti, ölüme karşı duyarlılık ya da duyarsızlık gibi pek çok iz kaçınılmaz bir şekilde varlığını sürdürmüştür. S. Aleksiyeviç’in "Son Tanıklar: Çocukluğa Aykırı Yüz Öykü" kitabında da artık kendi çocuklarını büyütmüş yetişkinlerin belleklerinde kalan İkinci Dünya Savaşı'nın kalıcı izleri kendini gösterir. Dolayısıyla da bu zorlu savaşta çocuk olmak o çocuğun yaşam çizgisini, geleceğe bakışını temelden değiştirecek bir unsur olarak karşımıza çıkar.

S. Aleksiyeviç'in kitabında, zamanın içinde yaşanan olayları ya da bu olayları yaşayan kişileri tekil olarak düşünmediği görülür. Her ne kadar birebir sohbetler sonucunda oluşturulmuş olsa da aslında her biri kendi sesi ile ortak bir şarkıyı seslendirmektedirler. Bu şarkıda acı, açlık, ölüm ve özlem vardır. S. Aleksiyeviç insan ruhunda yaşanmış ama gizli bir yerlerde hala varlığını koruyan bu duyguların bir aktarıcısı olmuştur. "Beni ruhun tarihi ilgilendiriyor. Ruhun gündelik varh̆ğ ilgilendiriyor... Kaçırılmış tarih benim uğraşı alanım” ( Aleksiyeviç, 2015) derken Rus insanının ruhunda hala varlığını sürdüren İkinci Dünya Savaşı'nın son tanıklarının yaşam gerçeklerini aktarır. Nitekim anlatıcılar arasındaki Valya Brinskaya da bundan sonraki neslin, savaş yıllarında yaşananları bilmesi gerektiğini ve bu sorumlulukla her şeyi anlattı̆̆ını ifade eder:

“.... Önce muhteşem annemiz ayrıldı aramızdan, sonra da babamız. İşte o an sezmisstik, o an hissettik; geride en son biz kalmıştı. Gidenlerin ardında bu kıyıda kalan son tanıklar biziz. Zamanımiz darahyor. Anlatmamiz gerek....

Anlattıklarımı son tanıklklar olacak..."(Aleksiyeviç, 2019: s. 291)

\section{Kaynakça}

Aleksiyeviç, Svetlana. (2019). Son Tanıklar- Çocukluğa Aykırı Yüz Öykü. (Çev: Aslı Takanay)İstanbul: Kafka.

Belge, Murat. (2016). Edebiyat Üzerine Yazılar. İstanbul: İletişim.

Emir, Badegül Can. (2016). Svetlana Aleksiyeviç’in Kaleminden Savaşan Kadın Anıları: Savaşın Kadınsı Bir Yüzü Yoktur. Yirminci Yüzyılda Savaş ve Kadın. Editör: Onur Yamaner, İstanbul: Bilge Kültür Sanat.

Freud, Sigmund. (2018). Savaş ve Ölüm Üzerine Düşünceler. (Çev: Elif Yıldırım). İstanbul: Oda.

Hobsbawm, Eric. (2010). Kısa 20. Yüzyıl-1914-1991 Aşırılıklar Çağı. (Çev: Yavuz Alogan) İstanbul: Everest.

Stone, Norman. (2019). İkinci Dünya Savaşı. (Çev: İbrahim Kapaklıkaya ) İstanbul: Ketebe.

Kaybedilmiş Bir Savaş Üzerine. https://www.5harfliler.com/kaybedilmis-bir-savas-uzerine-svetlanaaleksiyevicin-nobel-edebiyat-odulu-konusmasi/ Erişim (24.07.2021).

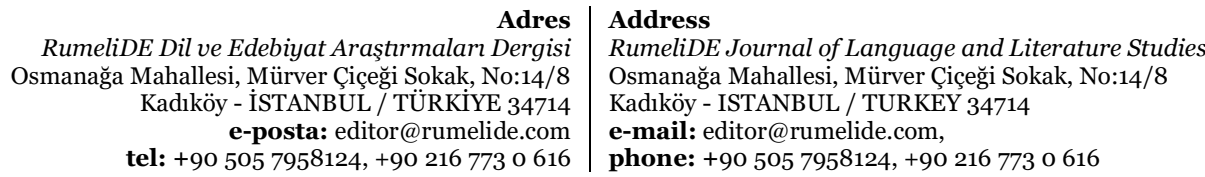

tel: +90 505 7958124, +90 2167730616

e-mail: editor@rumelide.com,
phone: +90 505 7958124, +90 2167730616 